\title{
CORPORATE SOCIAL RESPONSIBILITY AND TAX AGGRESSIVENESS IN PERSPECTIVE LEGITIMACY THEORY
}

\author{
Putri Sari $^{1}$, Wiwiek Prihandini ${ }^{2}$ \\ ABFI Institute Perbanas, \\ Email: Apendiputrii@gmail.com,wiwiek@perbanas.id
}

\begin{abstract}
The company as a business entity seeks to provide high dividends for shareholders. On the other hand as a corporate taxpayer, the company must set aside profits to pay taxes. Tax aggressiveness can be used to minimize this conflict. However, this action is not favored by shareholders because it can damage the company's reputation. With reference to legitimacy theory, corporate social responsibility (CSR) is considered as an action that can maintain the company's reputation. The question is whether corporate social responsibility influences tax aggressiveness. In fact the results of research on this subject are varied. This study aims to reexamine the effect of corporate social responsibility, from economic, social, and environmental dimensions towards tax aggressiveness. The test was conducted using 62 data from 31 companies listed on the Indonesia Stock Exchange during 2016-2017. Effective tax rate (ETR) is used to measure tax aggressiveness; CSR is measured using the valuation standard Global Reporting Initiative (GRI) 04. The results of the study stated that CSR economic dimensions have a positive effect on tax aggressiveness, whereas CSR social and environmental dimensions negatively affect tax aggressiveness. Recommendations, tax authorities can use the disclosure of environmental and social dimensions as an indication of the practice of tax aggressiveness.
\end{abstract}

Keywords: Corporate Social Responsibility (CSR), Tax Aggressiveness, Legitimacy Theory, Global Reporting Initiative (GRI).

\section{Introductoion}

Taxes are the biggest contributor to the State Budget (APBN), although Indonesia's tax ratio compared to other Asean countries is still low. In 2017 the contribution of the tax sector, specifically income tax (PPH) reached $52.6 \%$ of total state revenue (Ministry of Finance, 2017). This is shown in table 1.1 below.

Table 1.1

Tax Revenue Information (in trillion Rupiahs)

\begin{tabular}{lr} 
Jenis Pajak & $\begin{array}{c}\text { Kontribus } \\
\text { i }\end{array}$ \\
\hline PPh 21 & 148,5 \\
PPh 22 & 66,2 \\
PPh 23 & 37,9 \\
PPh 25/29 Badan & 248,6 \\
PPh $\quad 25 / 29$ & 20,5 \\
Pribadi & 162,6 \\
PPh Final & \\
\hline Pe: 2017 Ministry of Finance State Budget Data
\end{tabular}


Vol-3, Issue-4, 2019 (IJEBAR)

E-ISSN: 2614-1280 P-ISSN 2622-4771

https://jurnal.stie-aas.ac.id/index.php/IJEBAR

Based on table 1.1 above, PPh 25/29 agencies have the highest contribution of 248.6 trillion compared to other $\mathrm{PPh}$ subjects. The results of these contributions lead to conflict, where the corporate taxpayer in minimizing his tax payment has a purpose so that shareholder welfare can be maximized and company profits can be maximum (Wijayanti, Wijayanti, \& Samrotun, 2016). The contribution of the corporate taxpayer above cannot be said to be optimal because there are still phenomena regarding tax avoidance.

The phenomenon that occurred in 2014 (Andhari \& Sukharta, 2017) revealed that 12,000 samples studied were 4,000 companies that were not registered as taxpayers and did not carry out their tax obligations. The same thing was expressed in (Ningrum, 2017), in 2012 there were 4,000 foreign investment companies (PMA) reporting zero tax values in which some companies suffered losses for 7 consecutive years. This phenomenon shows that there are still many companies that try to avoid tax.

Tax avoidance is done by making tax planning both legally and illegally. Legally it is called tax avoidance and illegally it is called tax evasion (Agustina \& Aris, 2016). Tax avoidance can be divided into two, namely acceptable tax avoidance and unacceptable tax avoidance. Tax avoidance is not allowed to have other terms, namely aggressive tax planning and tax avoidance that are allowed defensive tax planning (Pohan, 2013).

The technique used in tax avoidance is by utilizing the weaknesses (gray areas) contained in taxation laws and regulations (Agustina \& Aris, 2016). An aggressive tax avoidance company scheme is by transfer pricing, thin capitalization, treaty shopping and controlled foreign corporation (CFC) (Darussalam, 2017). Aggressive tax avoidance actions cause a decrease in potential revenue from the taxation sector (Kurniawati \& Arifin, 2017). The reduced potential has an impact on reducing the funds allocated for community welfare programs (Noor, 2014). The community welfare program conducted by the company is an expense. As with tax payments, both of these incur double expenses for the company. One of the reasons why companies do tax aggressiveness is to cover costs incurred for public welfare programs (Pradnyadari \& Rohman, 2015).

Tax aggressiveness also causes damage to the company's reputation because the taxes paid have reduced the people's right to prosperity (Nusantari, Nuzula, \& Darono, 2015). But on the other hand, through the act of corporate tax aggressiveness can maximize CSR programs through economic, environmental and social dimensions to be able to enhance a positive reputation or a good image for the company (Laguir, Stagliano, \& Jamal, 2015). According to (Utari \& Rohman, 2015), corporate social responsibility for community welfare can be done through CSR programs. Where, several previous studies have linked the issue of CSR and tax aggressiveness. (Wijayanti, Wijayanti, \& Samrotun, 2016), revealed that CSR is a form of commitment to the company's activities to act properly, contribute to the economic, social and environmental development of the community.

The managerial policy of companies in conducting CSR programs is to increase public attention and gain legitimacy from the community (Lanis \& Richardson, 2013). In gaining community legitimacy, companies must be able to carry out responsibilities both in paying taxes and carrying out CSR. In this case, the value of a company will be guaranteed to develop in a sustainable manner if the company pays attention to the dimensions of CSR, namely the economic, environmental and social dimensions (Manurung \& Muid, 2015). Based on research (Laguir, Stagliano, \& Jamal, 2015) entitled "Does Corporation Social Responsibility affect corporate tax aggressiveness?" A positive effect of CSR on the economic dimension of tax aggressiveness can be found. the negative influence of social dimension CSR on tax aggressiveness and there is no influence of CSR environmental dimension on tax 
Vol-3, Issue-4, 2019 (IJEBAR)

E-ISSN: 2614-1280 P-ISSN 2622-4771

https://jurnal.stie-aas.ac.id/index.php/IJEBAR

aggressiveness. This is in line with research (Sari \& Adiwibowo, 2017) where the results of the study show that CSR economic dimensions have a positive effect on tax aggressiveness and CSR social dimensions negatively affect tax aggressiveness.

\section{Literature Review and Hypothesis}

\subsection{Legitimacy Theory}

Legitimacy theory is a company management system that is oriented to alignment with individuals, society and the government (Gray, Kouhy, \& Lavers, 2012). Meanwhile, according to (Purwanggono, 2015) the theory of legitimacy is an assessment or opinion given by the community to the company, in this case the goals to be achieved by the company. (Octaviana, 2014) states that there are two dimensions so that the company can get legitimacy support from the community. First, the company's organizational activities must be congruent with the value system in the community. Second, the reporting of company activities should also reflect social values. This theory tries to explain, when there is a difference between the activities carried out by the company and what is expected by the community, then management can use disclosure media. This action is a form of company statement that they have done what was expected (Lanis \& Richardson, 2013). This disclosure is done to reduce community concerns and ensure that the company has a concern for the community. This theory wants to explain the relationship between public awareness and disclosure by the company. In the perspective of legitimacy theory, companies will try to get recognition from the public. By way of carrying out activities in accordance with the norms that apply to the community in operating environment. The existence of a company is not solely to fulfill the wishes of shareholders but also the community in its operating environment. This condition will improve the company's image in the eyes of the public.

\subsection{Tax aggressiveness}

Tax aggressiveness is a tax avoidance activity where companies are involved in efforts to reduce effective tax rates (Harjito, Sari, \& Yulianto, 2017). While what was stated by (Indrajati, Djumena, \& Yuniarwati, 2017) tax aggressiveness is an act of manipulation of taxable income through tax planning actions. The tax planning action is the initial stage for systematically analyzing various alternative tax treatments with the aim of achieving the fulfillment of minimum tax obligations (Wijayanti, Wijayanti, \& Samrotun, 2016). Legal tax planning is called tax avoidance (Agustina \& Aris, 2016). Tax aggressiveness is included in tax avoidance which is not permitted. Where, the strategy taken is not in accordance with the expectations of the community and the government (Lanis \& Richardson, 2013). The government as tax recipient is disadvantaged by the act of tax aggressiveness because it can reduce revenue for the development of people's welfare. As for the community, the impact resulting from tax aggressiveness is that the community does not fully obtain and feel adequate facilities and support the welfare provided by the government (Cahyani, 2016).

Tax avoidance actions can pose risks for companies such as fines or loss of company reputation (Pradipta \& Supriyadi, 2016). Tax aggressiveness carried out can provide advantages and disadvantages for the company. The advantage obtained is to maximize the company's net profit and increase the distribution of cash to shareholders to be greater. The loss is the possibility of the company getting sanctions / penalties from tax authorities, and the decline in the company's stock price (Plorensia \& Hardiningsih, 2015). 
International Journal of Economics, Business and Accounting Research (IJEBAR)

Peer Reviewed - International Journal

Vol-3, Issue-4, 2019 (IJEBAR)

E-ISSN: 2614-1280 P-ISSN 2622-4771

https://jurnal.stie-aas.ac.id/index.php/IJEBAR

\subsection{Corporate Social Responsibility (CSR) in the Economic Dimensions of Corporate Tax Aggressiveness}

The economic dimension of CSR is a tool that raises managers' concerns in facing problems to all their stakeholders (Laguir, Stagliano, \& Jamal, 2015). Managers are required to produce maximum profit in the distribution of maximum dividends. And demanded to be able to balance all the interests of its stakeholders one of which is the burden to carry out CSR programs in getting positive legitimacy from the community (Purnomo, 2016).

This expense raises the manager's intention to pay a minimum tax to cover CSR expenses by not reducing cash or dividends distributed to shareholders. This is supported by previous research conducted by (Sari \& Adiwibowo, 2017) and (Laguir, Stagliano, \& Jamal, 2015) which states that CSR economic dimensions have a significant positive effect on corporate tax avoidance (tax aggressiveness). Based on the description above, the hypothesis can be formulated as follows:

\section{H1: CSR economic dimension has a positive effect on tax aggressiveness}

\subsection{Corporate Social Responsibility (CSR) in the Environmental Dimensions of Corporate Tax Aggressiveness}

CSR environmental dimension focuses on applying management to systematically manage the environmental impact of a company's operations in creating a product as a whole. Companies are required to be able to build credibility with external stakeholders and ensure that the principles of integrity and environmental protection have been carried out (Laguir, Stagliano, \& Jamal, 2015).

The legitimacy theory explains that managers are directed to enhance CSR activities in the environmental dimension in building positive recognition or a good image that can benefit the company (Wibowo Agung, 2012). In obtaining positive legitimacy the company must pay attention to impacts related to inputs (such as energy and water) and output (such as emissions, waste and effluents). Impacts related to the process of making products and services, compliance with environmental obligations and costs in waste treatment must be spent to support the comfort and welfare of the community (GRI, 2018).

Corporate expenses in protecting the environment and supporting the welfare of the community make managers try to minimize the tax burden to support the cost of environmental improvement from the impact of the company's operations (Hadjoh \& Sukartha, 2013). Previous research has linked the two CSR variables to the environmental dimension to tax aggressiveness. Research (Lanis \& Richardson, 2013) revealed that companies that carry out tax aggressiveness are said to be environmentally responsible. Where in other studies (Laguir, Stagliano, \& Jamal, 2015) stated that CSR environmental dimensions do not affect the actions of corporate tax aggressiveness. Based on the description above, the hypothesis can be formulated as follows:

\section{H2: CSR environmental dimension has a negative effect on tax aggressiveness}

\subsection{Corporate Social Responsibility (CSR) in the Social Dimensions of Corporate Tax Aggressiveness}

(Muzakki \& Darsono, 2015) states that in theory the legitimacy of the company will always try to create a balance between corporate values with social norms that exist in society. In supporting the sustainability of a good company or a good image, the company must be able to collaborate and establish relationships with internal and external company stakeholders (Cahyani, 2016).

The social dimension in CSR shows the company's concern in providing safety and comfort for employees. By prioritizing human rights to achieve prosperity, paying attention to the values 
International Journal of Economics, Business and Accounting Research (IJEBAR)

Peer Reviewed - International Journal

Vol-3, Issue-4, 2019 (IJEBAR)

E-ISSN: 2614-1280 P-ISSN 2622-4771

https://jurnal.stie-aas.ac.id/index.php/IJEBAR

and norms contained in society and taking responsibility for the products made. With this development it is possible for companies to act as good citizens to support social welfare (GRI, 2018).

CSR is a form of corporate social responsibility to the community environment and with a good tax payment; it is a form of social responsibility in supporting government performance. Thus, the actions of companies in carrying out tax aggressiveness can be influenced by their social attitudes. CSR social dimension has also been previously studied by (Laguir, Stagliano, \& Jamal, 2015) and (Sari \& Adiwibowo, 2017) which show the result that CSR social responsibility has a negative effect on tax aggressiveness. Where the negative influence occurs because the company has a high level of CSR social responsibility, it tends not to be aggressive in doing tax avoidance. Based on the description above, the hypothesis can be formulated as follows:

\section{H3: CSR social dimension has a negative effect on tax aggressiveness}

The research model that will be developed in this study refers to the hypotheses previously described. The following are the models in this research:

\section{Picture 1 \\ Research Model}

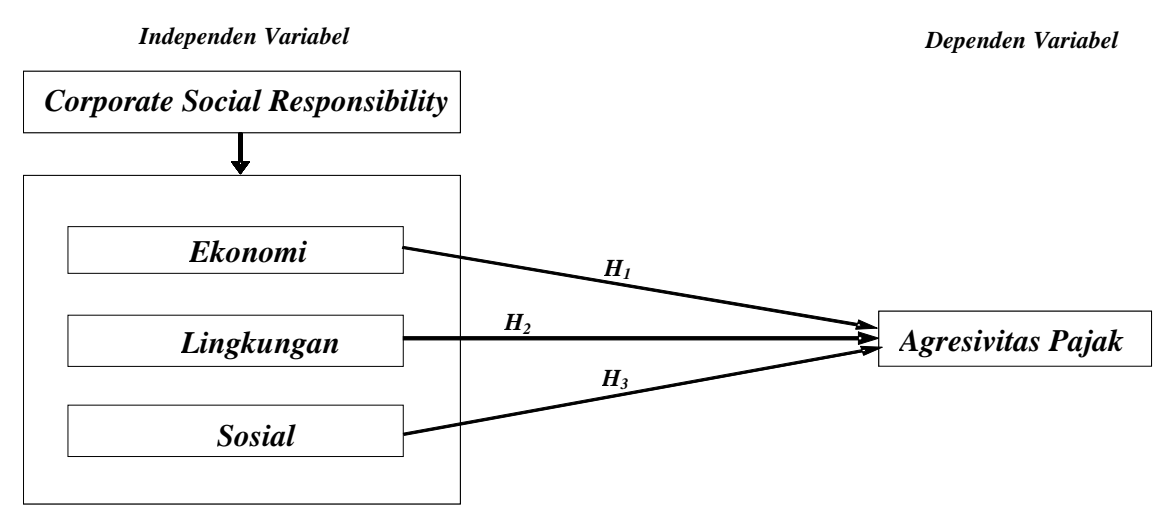

\section{Research methodology}

\subsection{Research Design}

This study aims to confirm the effect of CSR on tax aggressiveness. This type of quantitative research is hypothesis testing, using 4 observational variables namely, economic CSR, environmental CSR, social CSR, and tax aggressiveness. The unit of analysis used is the mining company, with a panel time scope. The population in this study were 52 mining companies listed on the Indonesian Stock Exchange (IDX) in the 2016 to 2017. The selection period was intended to find out the latest development trends of companies that take tax aggressiveness actions and carry out their social responsibilities. The sample technique in this study was carried out using the purpose sampling method or according to predetermined criteria. The resulting sample is 31 in 2 periods of financial statements and sustainability into 62 samples. With the following sampling criteria:

1. Companies that disclose CSR in annual reports on an ongoing basis

2. Companies that have positive profitability during the study period. 
International Journal of Economics, Business and Accounting Research (IJEBAR)

Peer Reviewed - International Journal

Vol-3, Issue-4, 2019 (IJEBAR)

E-ISSN: 2614-1280 P-ISSN 2622-4771

https://jurnal.stie-aas.ac.id/index.php/IJEBAR

3. Companies that present all required data.

\subsection{Variables Operationalization}

\section{Tax aggressiveness}

Tax aggressiveness in this study is the dependent variable (dependent). The main proxy for this research is the calculation of Effective Tax Rates (ETR). The lower the value of ETR produced by the company, the better it will be for the company because of its tax planning. While the higher the value of ETR, the company has been obedient in paying taxes. If the ETR has a value close to zero then it indicates the existence of tax aggressiveness (Indrajati, Djumena, \& Yuniarwati, 2017).

$$
\mathrm{ETR}=\frac{\text { tax paid }}{\text { income before tax }}
$$

\section{Corporate Social Responsibility (CSR)}

Corporate Social Responsibility (CSR) in this study uses a media check list that refers to the GRI 04 disclosure dimensions that have been adjusted to BAPEPAM No. regulation. VIII.G.2 regarding the company's annual sustainability report (Cahyani, 2016). The dimension items are divided into 3 dimensions and 91 items, namely 9 items of economic performance, 29 items of environmental performance, 14 items of labor practices, 9 items of human rights performance, 8 items of society and 9 items of product responsibility (Nugraha, 2015).

$$
\mathrm{CS}=\frac{\sum \text { number of CSR dimensions disclosed }}{\sum n=91}
$$

\section{Results and Discussion \\ 4.1 Result \\ Descriptive Analysis}

Table 4.3

\begin{tabular}{|c|c|c|c|c|c|}
\hline & $N$ & Min & $\operatorname{Max}$ & Mean & Std. Deviation \\
\hline Tax Aggressiveness & 31 & 0.00 & 0.55 & $\begin{array}{c}0.115 \\
2\end{array}$ & 0.13286 \\
\hline $\begin{array}{ll}\text { Corporate } & \text { Social } \\
\text { Responsibility } & \end{array}$ & 31 & 0.92 & 1,40 & $\begin{array}{c}1.191 \\
6\end{array}$ & 0.10325 \\
\hline Valid N (listwise) & 31 & & & & \\
\hline
\end{tabular}

Descriptive Descriptive Statistical Analysis

Source: SPSS Output 16.0

Based on Table 4.2 above, tax aggressiveness has a minimum value of 0.00 and a maximum value of 0.55 . This means that in the lowest tax payment period the company made 0.00 and the largest tax payable the company paid was 0.55 exceeding the corporate income tax rate of $25 \%$. Where when the tax aggressiveness has a value close to zero, it indicates that the company is increasingly aggressive in tax planning. The average value of tax aggressiveness of 0.1152 means that the tax aggressiveness of the company is relatively higher because the result is close to the minimum value of tax aggressiveness of 0.00 or below the $25 \%$ corporate income tax rate. 
International Journal of Economics, Business and Accounting Research (IJEBAR)

Peer Reviewed - International Journal

Vol-3, Issue-4, 2019 (IJEBAR)

E-ISSN: 2614-1280 P-ISSN 2622-4771

https://jurnal.stie-aas.ac.id/index.php/IJEBAR

Of the 31 sample companies that have been studied there are 29 companies that have a tax aggressiveness value below $25 \%$ or indicate the company has done an aggressive tax planning and the remaining 2 have a tax aggressiveness value above $25 \%$ which can be concluded that the company has been obedient in paying taxes. Std value The tax aggressiveness deviation of 0.13286 or greater than the mean value, this illustrates that the research data on tax aggressiveness in the period of 2 periods showed varied data.

CSR within 2 years is known to have an average value of 1.1916 , which means that the sample companies in this study averaged 119-120 items of CSR. The minimum value of CSR economic, environmental and social dimensions in the sample companies is 0.92 and the maximum value is 1.40 . it shows that all companies have fulfilled GRI 4 standard which states that the maximum value of the company in carrying out CSR economic, environmental and social dimensions is 182 items. Std value The CSR deviation of the economic, environmental and social dimensions is 0.10325 where the value is less than the mean value of 1.1916 which means the research data in the 2 CSR periods is less variable.

\section{Classic Assumption Test}

\section{Uji Autokorelasi}

Autocorrelation testing aims to determine the existence of autocorrelation in the period 2016 and 2017. This test is done through the Durbin-Watson test method and the test results are shown in the table below.

Table 4.4

Durbin-Watson Test Results

\begin{tabular}{ccccc}
\hline \multicolumn{5}{c}{ Change Statistics } \\
Model & $\begin{array}{c}\text { R Square } \\
\text { Change }\end{array}$ & F Change & Change & Chatson \\
\hline 1 & .650 & 16.725 & .000 & 2.048 \\
\hline
\end{tabular}

Source: SPSS Output 16.0

Based on the autocorrelation test results in table 4.4 above, it is known that the Durbin-Watson statistical value is 2.048. Where the Durbin-Watson statistical value is determined within the autocorrelation limit $\mathrm{dU}<\mathrm{DW}<(4-\mathrm{dU})$, it is known that the lower boundary value (dL) is 1.222 and the upper limit value ( $\mathrm{dU}$ ) is 1,650 , the implication is $1,650<2,048<2,3502,350$ values obtained from reduction results $(4-1,650)$. From these results it shows that the regression model in this study does not have an autocorrelation problem.

\section{Multicollinearity}

Multicollinearity testing is conducted to determine whether in the linear regression model there are intercorrelations or collinearities between CSR economic, environmental, social dimensions. These results are seen in table 4.5 below:

Tabl4 4.5

Multicollinearity Test

\begin{tabular}{llcccc}
\hline & & \multicolumn{4}{c}{ Collinearity Statistics } \\
& Model & $\boldsymbol{t}$ & Sig. & Tolerance & VIF \\
\hline 1 & (Constant) & 5.470 & .000 & & \\
& Economy & 3.447 & .002 & .976 & 1.024
\end{tabular}


International Journal of Economics, Business and Accounting Research (IJEBAR)

Peer Reviewed - International Journal

Vol-3, Issue-4, 2019 (IJEBAR)

E-ISSN: 2614-1280 P-ISSN 2622-4771

https://jurnal.stie-aas.ac.id/index.php/IJEBAR

\begin{tabular}{llll} 
Environment & -4.923 & .000 & .9111 .098 \\
Social & -2.555 & .017 & .9201 .087 \\
\hline
\end{tabular}

Source: SPSS Output 16.0

Based on the results of the multicollinearity test table 4.5 above, the Collinearity Statistics output shows the VIF CSR value of economic, environmental and social dimensions $<10$ and tolerance value $>0.10$, so it can be concluded that the three dimensions do not have multicollinearity disturbance in the linear regression model.

\section{Heteroscedasticity}

Heteroscedasticity testing in the linear regression model is carried out to produce homoscedasticity data. This test uses a scatterplot test. Based on the scatterplot graph in Figure 4.1 , it appears that the plot in the graph does not form a pattern or spread randomly. This shows that CSR residuals in the economic, environmental, social and tax aggressiveness dimensions have shown homoscedasticity.

Figure 4.1 Scatterplot

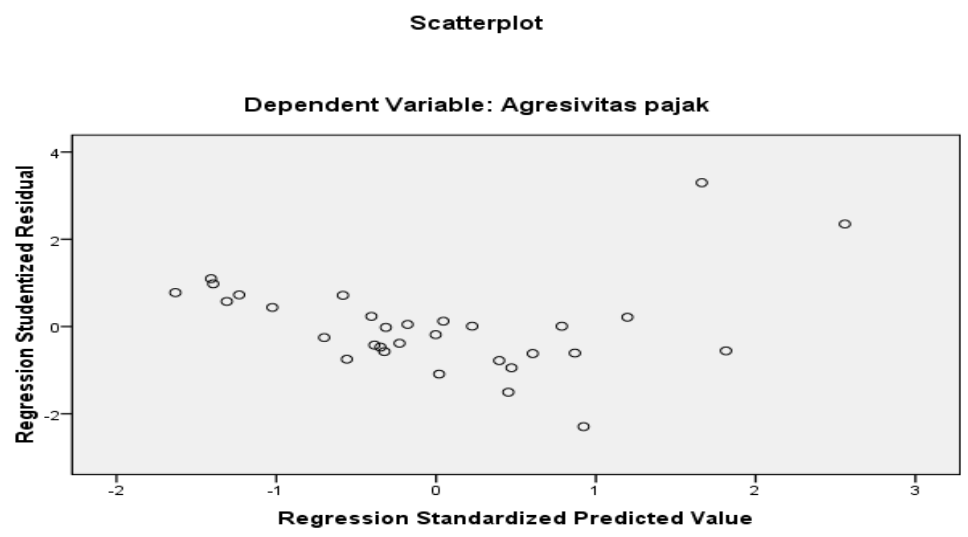

Source: SPSS Output 16.0

Multiple Linear Regression Test

Simultaneous Significance Test (F Statistical Test)

Table 4.8

F Statistical Test

\begin{tabular}{lccccc}
\hline Model & $\begin{array}{c}\text { Sum of } \\
\text { Squares }\end{array}$ & $\boldsymbol{d} f$ & $\begin{array}{c}\text { Mean } \\
\text { Square }\end{array}$ & $\boldsymbol{F}$ & Sig. \\
\hline 1 Regression & 0.344 & 3 & 0.115 & 16.72 & $0.000^{\mathrm{a}}$ \\
& & & & 5 & \\
Residual & 0.185 & 27 & 0.007 & & \\
Total & 0.530 & 30 & & & \\
\hline
\end{tabular}

Source: SPSS Output 16.0 
International Journal of Economics, Business and Accounting Research (IJEBAR)

Peer Reviewed - International Journal

Vol-3, Issue-4, 2019 (IJEBAR)

E-ISSN: 2614-1280 P-ISSN 2622-4771

https://jurnal.stie-aas.ac.id/index.php/IJEBAR

Based on the results in table 4.8, there is a simultaneous influence of economic, environmental and social dimensions with a significance level of 0,000. This Sig value is smaller than the 5\% significance level set in the F test. And in the ANOVA table it is known that the F count value is 16.725 and $\mathrm{F}$ table 2.91. Where $\mathrm{F}$ hit $>\mathrm{F}$ tab, it can be concluded that Ho is rejected and $\mathrm{Ha}$ is accepted, which means CSR economic, environmental and social dimensions have a significant influence on tax aggressiveness.

\section{Determination Coefficient Test}

Testing the coefficient of determination is done to find out how much the value of CSR economic, environmental and social dimensions in influencing tax aggressiveness. The results of the coefficient of determination test can be seen in table 4.9 below:

Table 4.9

Determination Coefficient Result

\begin{tabular}{lllll}
\hline Model & R & R Square & $\begin{array}{l}\text { Adjusted } \\
\text { Square }\end{array}$ & $\begin{array}{l}\text { R Std. Error of the } \\
\text { Estimate }\end{array}$ \\
\hline 1 & $0.806^{\mathrm{a}}$ & 0.650 & 0.611 & 0.8284 \\
\hline
\end{tabular}

Source: SPSS Output 16.0

Based on the results of regression processing in table 4.9, the $\mathrm{R}$ Square determination coefficient value of 0.650 is obtained. This means that the economic, environmental and social dimensions of CSR have the ability to explain their effect on tax aggressiveness by $65 \%$. While the remaining $35 \%$ is explained by other dimensions not included in this regression model such as profitability, inventory intensity, capital intensity, leverage and media exposure.

\section{Significance Test of Individual Parameters (t Statistics Test)}

$\mathrm{T}$ test is used to see whether CSR economic, environmental and social dimensions partially have a significant effect on tax aggressiveness. Based on the results of regression processing in table 4.10 below there are CSR coefficients of economic, environmental and social dimensions and constants to form linear regression equations.

Table4.10

T statistics test Result

\begin{tabular}{llcccrr}
\hline \multicolumn{1}{c}{} & \multicolumn{2}{c}{$\begin{array}{c}\text { Unstandardized } \\
\text { Coefficients }\end{array}$} & $\begin{array}{c}\text { Standardized } \\
\text { Coefficients }\end{array}$ & & \\
\multicolumn{1}{c}{ Model } & B & Std. Error & Beta & t & Sig. \\
\hline $1 \quad$ (Constant) & 1.014 & .185 & & 5.470 & .000 \\
Ekonomi & .182 & .053 & .397 & 3.447 & .002 \\
Lingkungan & -.551 & .112 & -.587 & 4.923 & .000 \\
Sosial & -.314 & .123 & -.303 & 2.555 & .017 \\
\hline
\end{tabular}

Source: SPSS Output 16.0 
Based on the Coefficients table, it can be seen that the value of $\mathrm{t}$-count and t-table obtained for CSR are:

1. Economic Dimensions: 3.447 ( $\mathrm{t}$ acount); 2,048 ( $\mathrm{t}$ table). so $\mathrm{t}$ count $>\mathrm{t}$ table, then Ho is rejected $\mathrm{Ha}$ is accepted, which means that the economy has a significant positive effect (significantly) on tax aggressiveness.

2. Dimensions of the Environment: 4,923 ( $\mathrm{t}$ count); 2,048 ( $\mathrm{t}$ table). So $\mathrm{t}$ count $>\mathrm{t}$ table, then Ho is rejected $\mathrm{Ha}$ is accepted, which means that the environment has a significant negative effect on tax aggressiveness.

3. Social Dimensions: 2.555 ( $\mathrm{t}$ count); 2,048 ( $\mathrm{t}$ table). So $\mathrm{t}$ count $>\mathrm{t}$ table, then Ho is rejected $\mathrm{Ha}$ is accepted, which means that socially significant negative effect (significantly) on tax aggressiveness.

4. Based on the results of data processing above, in the Unstandardized Coefficients column part B obtained a multiple linear regression equation, namely:

\section{$E T R=1,014+0,182_{E k}-0,551_{L k}-0,314_{\text {Sos }}$}

Based on these equations can be described as follows:

Constants $(\alpha)=1.014$, this means that the economic, environmental and social dimensions are considered constant then the level of tax aggressiveness (Y) is 1.014.

Coefficient Ek $(\beta 1)=0.182$, Economic dimensions of tax aggressiveness with a regression coefficient of 0.182 . This means that every time an economic dimension increases by $1 \%$, the tax aggressiveness will increase by 0.182 .

Coefficient $\mathrm{Lk}(\beta 2)=-0.551$, The environmental dimension of tax aggressiveness with a regression coefficient of -0.551 . This means that for every $1 \%$ increase in the environmental dimension, the tax aggressiveness will decrease by -0.551 .

Coefficient Sos $(\beta 3)=-0.314$, social dimension of tax aggressiveness with a regression coefficient of -0.314 . This means that every $1 \%$ increase in the social dimension, the tax aggressiveness will decrease by -0.314 .

\subsection{Discussion}

\section{The Economic Dimension of CSR Affects Tax Aggressiveness}

The t-test results of the economic dimension of CSR on tax aggressiveness are significantly positive. This shows that CSR economic dimension conducted by companies can reduce tax avoidance / tax aggressiveness. The results of this study support research (Yoehana, 2013) which reveals that the ability of companies to produce economic profitability has a high ETR (proxy of tax aggressiveness) so it is not identified to carry out tax aggressiveness. In contrast to research (Lanis \& Richardson, 2013) which revealed that when companies rely more on financing from debt than financing from equity for their operations, then the company will have a lower ETR or tax aggressiveness tends to occur. The results of this study are also different from research conducted by (Laguir, Stagliano, \& Jamal, 2015) and (Sari \& Adiwibowo, 2017) which states that CSR economic aspects have a positive effect on tax avoidance. That is, the higher the level of CSR economic dimension, the higher the level of aggressive or corporate tax avoidance. The results of this study are in line with the theory of legitimacy. Based on the phenomenon of social contracts between an organization and society, an organizational goal is needed that is in line with the values that exist in society. According to this theory, organizational actions must have activities and performance that are acceptable to society. This corporate value system is 
Vol-3, Issue-4, 2019 (IJEBAR)

E-ISSN: 2614-1280 P-ISSN 2622-4771

https://jurnal.stie-aas.ac.id/index.php/IJEBAR

demonstrated by the company's compliance with paying taxes and not trying to carry out tax aggressiveness activities that can harm the country. Therefore, companies should carry out social responsibility through disclosure of performance in annual reports, to gain positive trust from the public (Ratmono \& Sagala, 2015).

\section{Environmental and Social Dimensions Influence Tax Aggressiveness}

$\mathrm{T}$ test results from the environmental dimension of tax aggressiveness are significant negative. This shows that CSR environmental dimension can be used as an indication that the company is doing tax aggressiveness. The results of this study are different from the theory of legitimacy. In addition to being concerned with profits and increasing the wealth of shareholders, companies need to pay attention to environmental sustainability and the sustainability of the lives of surrounding communities to improve the good image of a company (Cahyani, 2016). The results of this study are not in line with research conducted by (Laguir, Stagliano, \& Jamal, 2015) that CSR environmental dimension does not affect the company's tax aggressiveness where the results of the $t$ value $<t$ table is equal to $0.2029<1.0509$. The results of the $\beta$ coefficient between the environmental dimensions of tax aggressiveness have a significant negative effect of $25.55 \%$. This shows that the increase in the social dimension of CSR by companies encourages companies to carry out tax aggressiveness. Thus more and more companies are expressing staffing issues,

industrial relations, and human rights, can be used as an indication that the company tends to avoid tax,

\section{Conclusions, Limitations and Suggestions}

\subsection{Conclusions}

Based on the results of the analysis conducted it can be concluded that: First, CSR economic dimensions have a positive effect on tax aggressiveness, it means that more disclosure of CSR economic dimensions will increase the value of the company's ETR. This means that corporate economic dimension CSR will reduce corporate tax aggressiveness. Therefore, more and more information about the economic value, the usefulness of infrastructure built, and the use of local resources revealed, can reduce the level of corporate planning for tax aggressiveness. Second, CSR environmental and social dimensions negatively affect ETR. The better the environmental dimension of CSR carried out by the company is indicated to increase the desire to carry out tax aggressiveness. This is contrary to the theory of legitimacy where companies that have good environmental responsibilities will reduce actions that can harm society.

\subsection{Limitations}

The discussion on CSR only refers to the theory, not looking at how laws and government regulations govern CSR for companies, especially mines. Tax aggressiveness is proxied by ETR, with the weakness of the ETR value can be positive or negative. So caution is needed in concluding positive and negative influences. A more accurate alternative is the ubnormal book tax difference. Even though this study uses data from mining companies (required to carry out CSR), only those listed on the Indonesia Stock Exchange (IDX).

\subsection{Suggestions}

For tax authorities, the results of this study can be used as an indication that the more disclosure of CSR environmental and social dimensions expressed in annual reports, there is a tendency for 
International Journal of Economics, Business and Accounting Research (IJEBAR)

Peer Reviewed - International Journal

Vol-3, Issue-4, 2019 (IJEBAR)

E-ISSN: 2614-1280 P-ISSN 2622-4771

https://jurnal.stie-aas.ac.id/index.php/IJEBAR

these companies to carry out tax avoidance strategies through costs incurred for social and environmental interests.

\section{References}

Agustina, T. N., \& Aris, M. A. (2016). Tax Avoidance : Faktor-Faktor yang mempengaruhinya (Studi Empiris Perusahaan Manufaktur yang terdaftar di BUrsa Efek Indonesia Periode 2012-2015). Seminar Nasional dan The 4th Call for Syariah Paper (ISSN 2460-0784), 113.

Andhari, P. A., \& Sukharta, I. M. (2017). Pengaruh Pengungkapan Corporate Social Responsibility, Profitabilitas, Inventory Intensity, Capital Intensity dan Leverage pada Agresivitas Pajak. E-Jurnal Akuntansi Universitas Udayana, 18 (ISSN: 2302-8556), 2115-2142.

Anita, F., Basri, Y. M., \& Julita. (2015). Pengaruh Corporate Social Responsibility, Leverage, Likuiditas, Dan Ukuran Perusahaan Terhadap agresivitas Pajak. Jom FEKON, Vol. 2 No. $2,1-15$.

Cahyani, R. (2016). Pengaruh Manajemen Laba Dan Corporate Social Responsibility Terhadap Agresivitas Pajak. UIN Journal, 15.

Darussalam. (2017, April Minggu). Beda Tax Planning, Tax Avoidance, dan Tax Evasion. 2017 , hal. 1-3.

Gray, R., Kouhy, R., \& Lavers, S. (2012). Corporate social and environmental reporting : a review of the literature and a longitudinal study of UK disclosure. Accounting, Auditing \& Accountability Journal, Vol. 8 (Issue: 2), pp.47-77, .

GRI. (2018). G4 Pedoman Pelaporan Keberlanjutan. Jakarta: Global Initiative Reporting.

Hadjoh, R. A., \& Sukartha, I. M. (2013). Pengaruh Ukuran Perusahaan, Kinerja Keuangan dan Eksposur Media pada Pengungkapan Informasi Lingkungan. E-Jurnal Akuntansi , 1-18.

Harjito, Y., Sari, C. N., \& Yulianto. (2017). Tax Aggressiveness Seen From Company Characteristics and Corporate Social Responsibility. Journal of Auditing, Finance, and Forensic Accounting , Vol. 5, Number 2 (ISSN: 2339-2886), 77-91.

Indrajati, D., Djumena, S., \& Yuniarwati. (2017). Faktor-Faktor yang mempengaruhi Agresivitas Pajak pada perusahaan Manufaktur yang terdaftar di BEI. Muara Ekonomi dan BIsnis , 1 (ISSN 2579-6224), 125-134.

Jessica, \& Toly, A. A. (2014). Pengaruh Pengungkapan Corporate Social Responsibility terhadap Agresivitas Pajak. Tax \& Accounting Review , 4 (1), 1-16.

Kemenkeu, A. (2017). Laporan Penerimaan APBN 2017. Jakarta: Kemenkeu.

Kurniawati, L., \& Arifin, H. (2017). Agresivitas Pajak dan Maturitas Uang. Jurnal Pajak Indonesia , 1, 92-106.

Laguir, I., Stagliano, R., \& Jamal, E. (2015). Does Corporation Social Responsibility affect corporate tax aggressiveness? Journal of cleaner production , 1-32.

Lanis, R., \& Richardson, G. (2013). Corporate social responsibility and tax aggressiveness: a test of legitimacy theory. Accounting, Auditing \& Accountability Journal , 26 (0951-3574), 75100.

Lubis, A. S. (2015). Pengelolaan Sumber Penerimaan Pajak sebagai Sumber Pendanaan Utama dalam Pembangunan. Anggaran dan Perbendaharaan, 1-6.

Manurung, E., \& Muid, D. (2015). Pengaruh Karakteristik Perusahaan terhadap Pengungkapan Tanggung Jawab Sosial. Diponegoro Journal of Accounting , Volume 4, Nomor 2 (ISSN (Online): 2337-3806), 1-9. 
International Journal of Economics, Business and Accounting Research (IJEBAR)

Peer Reviewed - International Journal

Vol-3, Issue-4, 2019 (IJEBAR)

E-ISSN: 2614-1280 P-ISSN 2622-4771

https://jurnal.stie-aas.ac.id/index.php/IJEBAR

Muzakki, M. R., \& Darsono. (2015). Pengaruh Corporate Social Responsibility dan Capital Intensity terhadap penghindaran pajak. Diponegoro Journal of Accounting , 1-14.

Ningrum, A. C. (2017). Analisis Faktor-Faktor Yang Mempengaruhi Penghindaran Pajak (Studi Empiris Pada Perusahan Manufaktur Yang Terdaftar di Bursa Efek Indonesia Periode 2013-2015). Journal Akuntansi , 1-17.

Noor, A. (2014). Debt to Equity Rule : Thin Capitalization dalam Perkembangan Investasi di Indonesia. Jurnal Penelitian Hukum , 1 No.3, 143-153.

Nugraha, N. B. (2015). Pengaruh Corporate Social Responsibility Dan Kepemilikan Mayoritas Terhadap Agresivitas Pajak. Diponegoro Journal of Accounting , 16-19.

Nusantari, N. I., Nuzula, N. F., \& Darono, A. (2015). Pengaruh Agresivitas Pajak Terhadap Pengungkapan Corporate Social Responsibility (Studi pada Perusahaan yang Terdaftar dalam Index SRI KEHATI tahun 2011-2013). Jurnal Administrasi Bisnis- Perpajakan , Vol.5 No.2, 1-8.

Octaviana, N. E. (2014). Pengaruh Agresivitas Pajak terhadap Corporate Social Responsibility : Untuk Menguji Teori Legitimasi. Diponegoro Journal of Accounting , 1-58.

Plorensia, W., \& Hardiningsih, P. (2015). Pengaruh Agresivitas Pajak dan Media Eksplosure terhadap Corporate Social Responsibility. Dinamika Akuntansi, Keuangan dan Perbankan , Vol. 4, No. 2 (ISSN :1979-4878), 136-151.

Pohan, C. A. (2013). Manajemen Perpajakan, strategi perencanaan pajak dan bisnis. Jakarta: PT. Gramedia Pustaka Utama.

Pradipta, D. H., \& Supriyadi. (2016). Pengaruh Corporate Social Responsibility (CSR), Profitabilitas, Leverage, dan Komisaris Independen Terhadap Praktik Penghindaran Pajak. UGM Journal , 1-25.

Pradnyadari, I. D., \& Rohman, A. (2015). Pengaruh Pengungkapan Corporate Social Responsibility terhadap Agresivitas Pajak. Diponegoro Journal Of Accounting, Volume 4, Nomor 2 (ISSN (Online): 2337-3806), Halaman 1-9.

Purnomo, L. C. (2016). Pengaruh Struktur Kepemlikan Perusahaan Terhadap Tindakan Pajak Agresif. Jurnal BPPK, Volume 9 Nomor 1, Halaman 99-108.

Purwanggono, E. A. (2015). Pengaruh Corporate Social Responsibility Dan Kepemilikan Mayoritas Terhadap Agresivitas Pajak. Diponegoro Journal of Accounting , 36.

Ratmono, D., \& Sagala, W. M. (2015). Pengungkapan Corporate Social Responsibility (Csr) Sebagai Sarana Legitimasi: Dampaknya Terhadap Tingkat Agresivitas Pajak. Jurnal Nominal , Volume Iv Nomor 2, 1-15.

Sari, L. L., \& Adiwibowo, A. S. (2017). Pengaruh Corporate Social Responsibility terhadap Penghindaran Pajak Perusahaan. Diponegoro Journal Of Accounting , Volume 6, Nomor 4, (ISSN (Online): 2337-3806), 1-13.

Sari, L. L., \& Adiwibowo, A. S. (2017). Pengaruh Corporate Social Responsibility terhadap Penghindaran Pajak Perusahaan. Diponegoro Journal Of Accounting , 6, Nomor 4 (ISSN Online 2337-3806), 1-13.

Utari, I. A., \& Rohman, A. (2015). Pengaruh Agresivitas Pajak Terhadap Corporate Social Responsibility : Untuk Menguji Teori Legitimasi (Studi Empiris Pada Perusahaan Manufaktur Yang Terdaftar Di Bursa Efek Indonesia Tahun 2011-2013). Diponegoro Journal of Accounting, Volume 04, Nomor 01, (ISSN (Online): 2337-3806), 1-13.

Wibowo Agung, E. S. (2012). CSR : dimensi dan perspektif dalam penelitian-penelitian empiris. Journal unimus Value Added, Vol. 8 No.2, 1-15. 
International Journal of Economics, Business and Accounting Research (IJEBAR)

Peer Reviewed - International Journal

Vol-3, Issue-4, 2019 (IJEBAR)

E-ISSN: 2614-1280 P-ISSN 2622-4771

https://jurnal.stie-aas.ac.id/index.php/IJEBAR

Wijayanti, A., Wijayanti, A., \& Samrotun, Y. C. (2016). Pengaruh karakteristik perusahaan, GCG dan CSR terhadap penghindaran pajak. Seminar Nasional IENACO (ISSN: 2337 4349), 541-548.

Yoehana, M. (2013). Analisis Pengaruh Corporate Social Responsibility Terhadap Agresivitas Pajak. Diponegoro Journal of Accounting , 30. 